\title{
Effect of Fluoride-Containing Solutions on the Surface of Cast Commercially Pure Titanium
}

\author{
Marcelo Bighetti TONIOLLO \\ Rodrigo TIOSSI \\ Ana Paula MACEDO \\ Renata Cristina Silveira RODRIGUES \\ Ricardo Faria RIBEIRO \\ Maria da Gloria Chiarello de MATTOS \\ Department of Dental Materials and Prosthodontics, Ribeirão Preto Dental School, \\ University of São Paulo, Ribeirão Preto, SP, Brazil
}

\begin{abstract}
This study evaluated the effects of fluoride-containing solutions on the surface of commercially pure titanium (CP Ti) obtained by casting. CP Ti specimens were fabricated and randomly assigned to 5 groups $(\mathrm{n}=10)$ : group 1: stored in distilled water at $37 \pm 1^{\circ} \mathrm{C}$; group 2: stored in distilled water at $37 \pm 1{ }^{\circ} \mathrm{C}$ and daily immersed in $0.05 \% \mathrm{NaF}$ for 3 min; group 3: stored in distilled water at $37 \pm 1{ }^{\circ} \mathrm{C}$ and daily immersed in $0.2 \% \mathrm{NaF}$ for $3 \mathrm{~min}$; group 4 : stored in distilled water at $37 \pm 1^{\circ} \mathrm{C}$; and immersed in $0.05 \% \mathrm{NaF}$ every 15 days for $3 \mathrm{~min}$; and group 5: stored in distilled water at $37 \pm 1^{\circ} \mathrm{C}$ and immersed in $0.2 \% \mathrm{NaF}$ every 15 days for 3 min. Surface roughness was measured with a profilometer immediately after metallographic polishing of the specimens (T0) and at 15-day intervals until completing 60 days of experiment (T15, T30, T45, T60). Data were analyzed statistically by ANOVA and Tukey's test $(\alpha=0.05)$. There was no statistically significant difference $(\mathrm{p}>0.05)$ in surface roughness among the solutions. In conclusion, fluoride-containing solutions (pH 7.0) used as mouthwashes do not damage the surface of cast CP Ti and can be used by patients with titanium-based restorations.
\end{abstract}

Key Words: fluorides, titanium, dental materials, surface properties.

\section{INTRODUCTION}

The increasing interest in using titanium in dentistry is due to good results of experiments using commercially pure titanium (CP Ti) in osseointegrated implants with great clinical success. Titanium has excellent properties such as good corrosion resistance, biocompatibility, low density, low thermal conductibility, good resistance, low weight and low cost (1). Studies have found that CP Ti can be properly cast and applied to the mold using adequate investment and casting techniques (2). Another property of CP Ti is passivity, which is the formation of a thin layer of oxides due its high reactivity with certain elements, oxygen especially, that provides high corrosion resistance and good adhesion of porcelain to metal (3). Biocompatibility with soft and hard tissues is a good advantage of $\mathrm{CP} \mathrm{Ti}$ compared to other metals and alloys. On the other hand, different products that are used in the oral cavity have innumerous substances that can interact with titanium. Fluoride is one this chemicals. It is present at different concentrations in dentifrices, mouthwashes and other sources like tablets, drops or chewing gums due to its well documented anticariogenic effect $(4,5)$.

Several authors have studied the corrosive action of fluoride over the protective passive layer of titanium and the large use of fluoride-releasing products in the oral cavity $(2,6,7-9)$. It has also been shown that the effects of prophylactic agents containing fluorides can be harmful to the mechanical properties of Ti alloys (10-12). Other studies have demonstrated that the exposure of titanium to any substance containing fluoride can lead to alterations on the surface topography and structure (13-15). The effects of fluoride present in different oral

Correspondence: Profa. Dra. Maria da Gloria Chiarello de Mattos, Departamento de Materiais Dentários e Prótese, Faculdade de Odontologia de Ribeirão Preto, USP, Avenida do Café, s/n, 14040-904 Ribeirão Preto, SP, Brasil. Tel: +55-16-3602-4098. Fax: +55-16-3633-0999. e-mail: gloria@forp.usp.br 
hygiene products on the surface of $\mathrm{CP}$ Ti after casting should be further investigated since little is known. The purpose of this study was to evaluate the effects of fluoride-containing solutions on the surface of cast CP Ti simulating regular use of mouthwashes by patients with titanium-based restorations.

\section{MATERIAL AND METHODS}

Fifty disc-shaped $(8 \mathrm{~mm}$ diameter and $2 \mathrm{~mm}$ high) wax patterns were invested in Rematitan Plus (Dentaurum, Pforzhein, Germany) and castings were made by the lost-wax technique using cp Ti (Tritan grade I; Dentaurum) in a casting machine (Discovery Plasma; EDG, São Carlos, SP, Brazil), which employs an electric arc melting in vacuum under an argon atmosphere, with injection of the metal into the mold by vacuum pressure, according to manufacturer's instructions. The 50 cast specimens were carefully cleaned using $50-\mu \mathrm{m}$ aluminum oxide airborne particle abrasion for $15 \mathrm{~s}$ to remove investment debris. The specimens were ground wet with 180-, 400-, 600-, 800-, 1000- and 2000-grit silicon carbide papers, and were then ultrasonically cleaned in ethanol for $15 \mathrm{~min}$ and washed with distilled water. Five groups of $10 \mathrm{CP}$ Ti specimens each were formed according to the fluoride-containing solutions in which the specimens were immersed during the experiment, the immersion times and the intervals at which surface roughness readings were performed (Table 1). The sodium fluoride solutions $(\mathrm{pH} 7.0)$ were prepared at the School of Pharmaceutical Sciences of Ribeirão Preto, University of São Paulo, Ribeirão Preto, SP, Brazil.

Surface roughness of the CP Ti specimens was measured with a profilometer (Mitutoyo SJ201-P, 300 $\mu \mathrm{m}$ accuracy, $0.5 \mathrm{~mm} / \mathrm{s}$ speed, and five $0.8 \mathrm{~mm}$ cut-offs). Three readings were made in each specimen (on the center of the specimen, $1 \mathrm{~mm}$ to the right and $1 \mathrm{~mm}$ to the left) and a mean value was calculated for each specimen and the for the group. All 50 specimens remained immersed in distilled water throughout the experiment at $37^{\circ} \mathrm{C} \pm 1^{\circ} \mathrm{C}$ temperature. In the experimental groups, the specimens were repeatedly removed for immersion in the fluoride-containing solutions and returned to the distilled water until the end of the experimental period.

The surface roughness data underwent statistical analysis and the assumptions of homogeneity of variances and normal distribution of errors were tested for the response variables evaluated. As normal distribution was observed, data were analyzed statistically by ANOVA and Tukey's test at 5\% significance level using JMP 7.0 statistical software (SAS Institute Inc., Cary, NC, USA).

\section{RESULTS}

Table 2 shows means values and standard deviations of surface roughness $(\mu \mathrm{m})$ for each group at the different reading intervals (T0-T60). No statistically significant difference differences ( $p>0.05$ ) in surface roughness were observed among the groups or reading intervals.

\section{DISCUSSION}

Finding an ideal restorative material to replace missing teeth and/or improve the properties of existing materials in the attempt to increase longevity of prosthetic restorations has been one of the greatest challenges in dentistry. Metal alloys and their different formulations are among the materials used for rehabilitations and

Table 1. Distribution of the groups according to the-containing solutions, immersion times and intervals of surface roughness readings.

\begin{tabular}{|c|c|c|c|}
\hline $\begin{array}{l}\text { Group } \\
(n=10)\end{array}$ & $\begin{array}{l}\text { Fluoride- } \\
\text { containing } \\
\text { solution }\end{array}$ & $\begin{array}{l}\text { Immersion } \\
\text { time }\end{array}$ & $\begin{array}{c}\text { Surface } \\
\text { roughness } \\
\text { reading } \\
\text { intervals }\end{array}$ \\
\hline $\begin{array}{c}1 \\
\text { (control) }\end{array}$ & --- & --- & $\begin{array}{l}\mathrm{T} 0 \text { : initial } \\
\text { reading, after } \\
\text { polishing }\end{array}$ \\
\hline 2 & $\begin{array}{c}0.05 \% \mathrm{NaF} \\
\text { aqueous solution }\end{array}$ & $3 \mathrm{~min} /$ day & $\begin{array}{c}\text { T15: after } 15 \\
\text { days }\end{array}$ \\
\hline 3 & $\begin{array}{c}0.2 \% \mathrm{NaF} \\
\text { aqueous solution }\end{array}$ & $3 \mathrm{~min} /$ day & $\begin{array}{c}\text { T30: after } 30 \\
\text { days }\end{array}$ \\
\hline 4 & $\begin{array}{c}0.05 \% \mathrm{NaF} \\
\text { aqueous solution }\end{array}$ & $\begin{array}{c}3 \mathrm{~min} / \text { day } \\
\text { every } 15 \text { days }\end{array}$ & $\begin{array}{c}\text { T45: after } 45 \\
\text { days }\end{array}$ \\
\hline 5 & $\begin{array}{c}0.2 \% \mathrm{NaF} \\
\text { aqueous solution }\end{array}$ & $\begin{array}{c}3 \mathrm{~min} / \text { day } \\
\text { every } 15 \text { days }\end{array}$ & $\begin{array}{c}\text { T60: after } 60 \\
\text { days }\end{array}$ \\
\hline
\end{tabular}


play an important role in the longevity of restorations. In the past few decades, the increasing use of CP Ti for dental implants has raised hopes for treatment of partial or complete edentulism. In the oral cavity, $\mathrm{CP}$ Ti is used for dental implants, brackets, wires or lingual arches, and is in direct contact with corrosive products dissolved in the saliva or the crevicular fluid (14).

The quality of a dental alloy is determined by its biological, structural, physical and technological aspects. Among them, corrosion resistance is always considered the main factor to be observed, since fracture resistance and esthetics of the rehabilitation are directly related to this property. The corrosion behavior of a titanium alloy depends on an oxide film, composed of $\mathrm{TiO}_{2}$ mainly, which spontaneously covers the surface of titanium and its alloys in the presence of oxygen (10).

The oral environment contributes to corrosion because of its temperature and $\mathrm{pH}$ variation, humidity, oxygen presence and food decomposition. Fluoride is one of the chemicals that can alter alloy surface and is mainly present in mouthwashes and dentifrices at different concentrations. The effects of fluoride on the corrosion behavior of titanium and its alloys have been presented by several authors $(12,14)$. According to their results, the oxide film undergoes a reaction when in contact with fluoride-containing solutions, resulting in

Table 2. Surface roughness of the CP Ti specimens in the groups $(\mu \mathrm{m})$.

\begin{tabular}{cccccc}
\hline \multirow{2}{*}{ Groups } & \multicolumn{5}{c}{ Time (days) } \\
\cline { 2 - 6 } & 0 & 15 & 30 & 45 & 60 \\
\hline \multirow{2}{*}{1} & 0.25 & 0.19 & 0.27 & 0.13 & 0.14 \\
& $(0.05)$ & $(0.05)$ & $(0.09)$ & $(0.04)$ & $(0.04)$ \\
2 & 0.25 & 0.22 & 0.24 & 0.12 & 0.17 \\
& $(0.06)$ & $(0.04)$ & $(0.06)$ & $(0.03)$ & $(0.09)$ \\
3 & 0.18 & 0.20 & 0.19 & 0.10 & 0.11 \\
& $(0.04)$ & $(0.06)$ & $(0.04)$ & $(0.01)$ & $(0.03)$ \\
4 & 0.23 & 0.26 & 0.22 & 0.13 & 0.13 \\
& $(0.07)$ & $0.13)$ & $(0.04)$ & $(0.04)$ & $(0.06)$ \\
& 0.24 & 0.25 & 0.28 & 0.13 & 0.13 \\
5 & $(0.06)$ & $(0.09)$ & $(0.11)$ & $(0.04)$ & $(0.02)$ \\
\hline
\end{tabular}

Values are expressed as mean (standard deviation). G1 (control) $=$ No immersion; $\mathrm{G} 2=0.05 \% \mathrm{NaF}$ aqueous solution; $\mathrm{G} 3=0.2 \%$ $\mathrm{NaF}$ aqueous solution; $\mathrm{G} 4=0.05 \% \mathrm{NaF}$ aqueous solution; $\mathrm{G} 5=$ $0.2 \% \mathrm{NaF}$ aqueous solution. the formation of titanium fluoride, titanium oxide fluoride, or sodium titanium fluoride on the surface of the alloys and marked decrease in the corrosion resistance of these solutions (10).

The fact that titanium is corroded in fluoride mediums and especially in acid-fluoride solutions is to be watched in dental practice. When titanium is exposed to acidulated topical fluoride agents, it is suggested that hydrofluoric acid (HF) is produced and dissolves the protective oxide layer on the surface of titanium and its alloys $(12,16)$. Corrosion can affect or not alloys' chemical composition or the material's surface microstructure. Metallic ions freed by corrosion are dependant of various characteristics such as surface roughness, oxidation degree, speed of the solution's mixture at average temperature, the presence of inhibitors and alloy's abrasion.

This study found that the mean values of surface roughness of CP TI specimens exposed to solutions containing fluoride ( $\mathrm{pH}$ 7.0) at different concentrations and with different immersion protocols were statistically similar. These results differ from those of a previous study (14). The tendency of lower roughness values after 30 days of exposure and macroscopic changes in the coloration of specimens after exposure to fluoride (17) has to be investigated.

Mabilleau et al. (14) have described an important increase in the roughness of disks immersed in fluoridated saliva which was noticed after 9 days of immersion. Surface roughness $(R a)$ increased regularly and the difference to the baseline was noticeable in the first day. This result indicates that the attacks to the oxide layer and underlying titanium were progressive. Moreover, when a high concentration of $\mathrm{F}^{-}(2.5 \%)$ was used, crystalline deposits were observed on the surface of Ti disks. On the other hand, Huang (13) showed a dissimilar influence on the surface morphology of commercial NiTi archwires, regardless of the archwire manufacturer. By comparing, the lower fluoride-containing $(<2500 \mathrm{ppm})$ test environments (such as commercial mouthwashes and artificial saliva added with dentifrices or low-fluoride prophylaxis gel) had no considerable influence on the surface morphology variation after the 28-day of immersion tests. A significant surface morphology change, namely more severe corrosion morphology, was observed on the NiTi archwires immersed in higher fluoride-containing environments, i.e. NUPRO, fluoride gel-containing artificial saliva. 
Prescribing fluoride-containing products should be careful and controlled, since increasing the use of such products can lead to alterations in restoration surface, compromising the longevity of the treatment. However, in the present study using surface roughness readings, those alterations were not detected. Although no significant differences were found among the different solutions, periodical evaluation of patients subjected to such treatments is recommended.

Although in the present study no significant differences were found among the groups, the lack of surface roughness increase is a clinically important finding because it implies in less possibility of adhesion of residues and microorganisms to denture surface. However, further studies are necessary to elucidate the corrosion resistance of with CP Ti exposed to mouthwash solutions containing fluoride.

Under the conditions of this study, it may be concluded that fluoride-containing solutions do not damage the surface of casted CP Ti and can be used as mouthwashes by patients with titanium-based restorations.

\section{RESUMO}

Este estudo avaliou o efeito de soluções para enxaguatório bucal contendo fluoreto sobre a superfície do titânio comercialmente puro (cp Ti) após fundição odontológica. As amostras $(n=50)$ foram divididas igualmente: grupo A - armazenadas em água destilada a $37 \pm 1^{\circ} \mathrm{C}$, grupo $\mathrm{B}$ - armazenadas em água destilada a $37 \pm 1^{\circ} \mathrm{C}$ e imersão diária em $\mathrm{NaF}$ a $0,05 \%$ durante 3 min, grupo $\mathrm{C}$ - armazenadas em água destilada a $37 \pm 1{ }^{\circ} \mathrm{C}$ e imersão diária em $\mathrm{NaF}$ a $0,2 \%$ durante 3 min, grupo D - armazenadas em água destilada a $37 \pm 1{ }^{\circ} \mathrm{C}$ e imersão em $\mathrm{NaF}$ a $0,05 \%$ a cada 15 dias por 3 min e grupo $\mathrm{E}$ - armazenadas em água destilada a $37 \pm 1{ }^{\circ} \mathrm{C}$ e imersão em $\mathrm{NaF}$ a $0,2 \%$ a cada 15 dias durante 3 min. A rugosidade superficial foi medida logo após o polimento metalográfico das amostras (T0) e cada 15 dias de experiência até serem alcançados 60 dias (T15, T30, T45, T60). Os dados foram analisados usando ANOVA $(\alpha=0,05)$ e as diferenças não foram estatisticamente significantes $(p>0,05)$ entre as diferentes soluções. Conclui-se que soluções contendo fluoreto $(\mathrm{pH} 7,0)$ não danificam a superfície do Ti cp e podem ser usadas como soluções para bochecho usadas por pacientes que possuem restaurações à base de titânio.

\section{ACKNOWLEDGEMENTS}

The authors acknowledge FAPESP (grant \# 2006/55565-9) for financial support.

\section{REFERENCES}

1. Ohkubo C, Hanatani S, Hosoi T. Present status of titanium re- movable dentures - a review of the literature. J Oral Rehabil 2008;35:706-714.

2. Di Carlo F, Cassinelli C, Morra M, Ronconi LF, Bassi MA, De Muro G, et al.. Corrosion of titanium in presence of dental amalgams and fluorides. Minerva Stomatol 2003;52:111-121.

3. Hanawa T, Kon M, Ohkawa S, Asaoka K. Diffusion of elements in porcelain into titanium oxide. Dent Mater J 1994;13:164-173.

4. Chedid SJ, Cury JA. Effect of $0.02 \% \mathrm{NaF}$ solution on enamel demineralization and fluoride uptake by deciduous teeth in vitro. Braz Oral Res 2004;18:18-22.

5. Bijella MFTB, Brighenti FL, Bijella MFB, Buzalaf MAR. Fluoride kinetics in saliva after the use of a fluoride-containing chewing gum. Braz Oral Res 2005;19:256-260.

6. Kedici SP, Aksut AA, Kiliçarslan MA, Bayramoglu G, Gokdemir $\mathrm{K}$. Corrosion behavior of dental metals and alloys in different media. J Oral Rehabil 1998;25:800-808.

7. Nakagawa M, Matono Y, Matsuya S, Udoh K, Ishikawa K. The effect of Pt and Pd alloying additions on the corrosion behavior of titanium in fluoride-containing environments. Biomaterials 2005;26:2239-2246.

8. Schiff N, Boinet M, Morgon L, Lissac M, Dalard F, Grosgogeat B. Galvanic corrosion between orthodontic wires and brackets in fluoride mouthwashes. Eur J Orthod 2006;28:298-304.

9. Schiff N, Grosgogeat B, Lissac M, Dalard F. Influence of fluoride content and $\mathrm{pH}$ on the corrosion resistance of titanium and its alloys. Biomaterials 2002;23:1995-2002.

10. Kaneko K, Yokoyama K, Moriyama K, Asaoka K, Sakai J, Nagumo M. Delayed fracture of beta titanium orthodontic wire in fluoride aqueous solutions. Biomaterials 2003;24:2113-2120.

11. Yokoyama K, Kaneko K, Moriyama K, Asaoka K, Sakai J, Nagumo M. Delayed fracture of Ni-Ti superelastic alloys in acidic and neutral fluoride solutions. J Biomed Mater Res A 2004;69:105113.

12. Walker MP, White RJ, Kula KS. Effect of fluoride prophylactic agents on the mechanical properties of nickel-titanium-based orthodontic wires. Am J Orthod Dentofacial Orthop 2005;127:662669.

13. Huang HH. Variation in surface topography of different NiTi orthodontic archwires in various commercial fluoride-containing environments. Dent Mater 2006;23:24-33.

14. Mabilleau G, Bourdon S, Joly-Guillou ML, Filmon R, Basle MF, Chappard D. Influence of fluoride, hydrogen peroxide and lactic acid on the corrosion resistance of commercially pure titanium. Acta Biomater 2006;2:121-129.

15. Stajer A, Radnai M, Pelsoczi KI, Turzo K, Oszko A, Fazekas A. The effect of fluorides on the surface structure of titanium implants. Fogorv Sz 2006;99:53-59.

16. Toumelin-Chemia F, Rouellet F, Burdairon G. Corrosive properties of fluoride-containing odontologic gels against titanium. J Dentistry 1996;24:109-115.

17. Watanabe I, Watanabe E. Surface changes induced by fluoride prophylactic agents on titanium-based orthodontic wires. Am J Orthod Dentofacial Orthop 2003;123:653-656. 